\title{
TURKEY'S VERNACULAR DISCOURSES ${ }^{1}$
}

TÜRKIYE'DE VERNAKÜLER SÖYLEMLER

ANKARA UNIVERSTTY JOURNAL

SOCIAL SCIENCES

10.33537/sobild.2020.11.1.2

\section{Makale Bilgisi}

Gönderildiği tarih: Kabul edildiği tarih: Yayinlanma tarihi:

31-10-2019 16-01-2020 31.01 .2020

Article Info

Date submitted: Date accepted:

Date published:

31-10-2019

16-01-2020

31.01 .2020

\section{Keywords}

Vernacular, architecture, essentialism, ideological fantasy, slovaj žižek

\section{Anahtar sözcükler}

Vernaküler, mimarlık, özcülük, ideolojik fantazi, slovajžižek

\section{Abstract}

Although vernacular architecture is one of the most popular fields of discourse production in Turkey, no practice of literature exists in this field that is as productive and varied. Thus, this paper primarily intends to analyze the writings of a group of researchers regarded to be the representatives of the early period of this field, through a set of arising questions. An overview of the vernacular discourse which is dealt with in the first part of the article demonstratres that different writers have similar discoursesrecurring over the years. These discourses, and their linguistic and theoretical characteristics, are defined as "essentialism" oriented in the article, for they intend to draw boundaries particularly by assigning appellations for the houses, identify the main components, and determine origins. The essentialism oriented vernacular discourses create the perception that traditional houses have specific values and associate the societal values of "true" and "real" with these houses. However, those who attach certain values to structures and societies are obviously the people themselves who generate these discourses. To shed light onto the ideological nature of essentialism oriented vernacular discourses, the second part of the article analyzes the Turkish discourse on vernacular through the "unspoken" rather than the already spoken. To this end, it questions the subconscious of the vernacular rather than reads it for direct meaning. With this psychoanalytical reading, it aims to deal with both the spoken and unspoken aspects of Turkish vernacular discourse.

\footnotetext{
${ }^{1}$ This text is a reproduced version of the writer's two different studies published in Arredamento Journal of Architecture: "Essentialism in the Vernacular Architecture Discourse: Questions Awaiting Answers", 2018, issue 324,, pages 92-97 and "Vernacular as an Ideological Fantasy ", 2019, issue: 329, pages 92-93.
}

\section{$\ddot{o} z$}

Vernaküler mimarlık Türkiye'de en sevilen söylem üretim alanlarından biri olmasına rağmen aynı alanda verimli ve çeşitlilik gösteren bir yazım etkinliği yok. Bu sebeple bu makale öncelikle bu söylem üretim bölgesinin erken evresini temsil eden bir grup araștırmacinin yazdikların, akla getirdiği sorular çerçevesinde irdeliyor. Makalenin birinci bölümünde ele alınan vernaküler söylemler alanina bakıldiğında, farklı yazarların söylemlerinin birbirine benzediği ve yıllar boyunca bu söylemlerin yinelendiği görülüyor. Bu söylemler; içeriğinde kullanılan dil ve kuramlar, söz konusu konutlarin adından başlayarak sinır çizmeye, temel bileşenleri belirlemeye ve köken tespit etmeye yönelik olduğundan makalede "özcülük" merkezli olarak nitelendiriliyor. Özcülük merkezli vernaküler söylemlerde geleneksel konutlarn sanki özgül bir değeri varmiş algisı yaratılmakta, toplumun "doğru", "gerçek" değerlerinin bu konutlarda olduğu düşündürülmekte. Oysaki bu değerleri yapılara ya da topluma verenlerin, söz konusu söylemleri üretenler olduğu ortada. Makalenin ikinci bölümde ise Türkiye'de özcülük merkezli vernaküler söylemlerin ideolojik yapisinı anlamak için vernakülerle ilgili söylemler, söylenenler üzerinden değil "söylenmeyenler" üzerinden ele aliniyor. Bunun için vernakülerin düz anlamlı bir okumasinı yapmak yerine, vernakülerin bilinçaltında neler olduğu sorgulanıyor. Yapilan bu psikanalitik okuma ile birlikte makale Türkiye'de vernaküler söylemlerin hem görünen hem de görünmeyen yanını ele almaya çalışıyor. 


\section{Vernacular Revisited}

Quite rare as they are in current theories, the effects of architectural discourses based on social and physical determinism have reached the present time. This can be clearly observed in the discourses disregarding the relation between the space and sociality, and is especially widespread in the architectural vernacular discourse generated in Turkey. It iscommon practice to base the evaluation ofa space/structure on physical and social determinism. Though it is undeniable that architecture is a component of socialty in the everyday life, this fact hardly reflects on discourses. This study problematizes why the socialty of space rarely attracts any attention although its ignorance in the vernacular architectural discourses is quite obvious and why deterministic approaches are readily accepted.

In physical determinist discourses, space is considered solely with it sphysical characteristics. According to Lefebvre, until recently, space was associated with nothing but a geometrical concept, and it coexisted with the terms "Euclidian space", "isotropic" or "infinite". The general conception was that space almost only derived from mathematics. The term "Social Space" was literally astonishing (Lefebvre, 2015, 33). The discourses based on social determinism conceive of "a society comprised of social relations only" (Durkheim, 2016, 17).

Here, a social phenomenon can only be explained through another social phenomenon, and objects and artefacts do not play a role in the development of socialty. For example, Durkheim asserts that objects do not contain anything compulsory to stimulate social evolution: "They are the elements that constitute the practice aspect of vital forces in society; however, they do not generate a vital force by themselves. Then, what is left behind as an active element is literally a human environment" (Durkheim, 2016, 140). Put briefly, if socialty taking place in a space is disregarded during an attempt to understand it, one is geared towards a physical determinist direction; on the other hand, if the fact that space constructs socialty is disregarded during an attempt to understand socialty in a space, one is directed towards social determinism.

In the vernacular discourse, implementation of social and physical determinism together is also very common. Conflicting as they are at first sight, they support one another, so shedding light on this interaction is more important than abstract theoretical discussions. In this study, as also maintained by Benjamin in a discussion about the method $^{2}$ (Benjamin, 1993, 42), the accumulation of phenomena itself is inherently the theory. This has not been considered sufficiently probably because it was not attached enough of importance 3 (Benjamin, 1993, 35). However, it does not necessarily

2 17. Passage: "The ultimate culmination of historicism is, by its law, universal history. Materialist historiography is perhaps most remarkably distinguished from such a history by its methodology. The former does not have theoretical quality. Its methodology is mere collection: It uses a pile a phenomena to fill in coherent or broken time (...)".

3 “The methodology of this project is literary montage. I don't not need to say anything. All I need to do is show. I will neither resort mean that they are worthless or incredible just because they are not analyzed and theorized. By contrast, determinist discourses even create various mystifications not only in architecture but in several other fields.

This paper intends to adopt an objective stance, trying to reveal the agreements between similar discussions held for a long time by different people and scrutinizing the validity of several discourse, the correctness of which seems out of question. It was entitled as "the vernacular", for it was the least "consumed" of numerous terms with similar meanings ${ }^{4}$.

To this end, of the researchers who have focused on vernacular architecture in Turkey, Sedad Hakk1 Eldem, Erdem Aksoy, Önder Küçükerman, Ayda Arel, Cengiz Bektaş, and Doğan Kuban, were included into the scope of this study. Nevertheless, it is impossible to discuss the statements of each in a detailed way within the scope of a single article. Even a glimpse at one will show that their content goes well beyond the scope of this article. Therefore, the present study mostly refers to statements by Sedad Hakk1 Eldem, incorporating relevant examples from other writers. Excerpts are then analyzed and deconstructed. Certain phrases and concepts are written in bold face fonts to attract the attention of the reader, and no other intervention was employed. Here the main aim is to unravel the subtle conflicts and desires between the lines of these quotations.

\section{Sedad Hakkı Eldem}

"One can easily observe that even the houses built hundreds of kilometers away from each other and under different circumstances have architectural plans that are essentially always the same. Accordingly, the main element that connects miscellaneous types of Turkish houses to each other and establishes unity between them is the plan.

"Just as the organization, structure, and to some extent, volume of a house are expressed by the plan, its economic and social state are displayed on it.

"Hence, plan is the major aspect in the analysis of the type of a house" (Eldem, 1968, 12).

"The upper floor has remained to be the main floor, or the most honorable floor" (Eldem, 1968, 13).

"The main components of the plan are as follows: 1 . Rooms, 2. Sofas (anterooms) and Müştemilat (outbuildings), 3. Walkways and stairs. Other elements have little, if any, effect on the design" (Eldem, 1968, 14).

How can one expect the houses to remain the same while there are changes in time and space? How can "plan" remain "the same" forever regardless of the content

to fancy styles, nor will I steal anything from the treasure. Just the leftovers, just the garbage, which I can no way describe, so all I will do is exhibit them".

${ }^{4}$ Numerous near-synonyms exist such as civil architecture, folk architecture, local architecture, traditional architecture, architecture without architects, spontaneous, "indigenous", primitive, ethnic, folkloric, anonymous, regional architecture. 
of place and time? Is it possible to make generalizations on plans without considering time and space? Considering the complexity and multi-dimensions of the architectural reality, how isthispossible to establish a hierarchy based on plans only? How does plan, just one of the tools of a structure's architectural representation, achieve "unity" connecting multiple concepts to each other? What does such a vision of unity mean? To what extent isitplausible to produce lists of basic constituents like "main components"? How much is ignored by the use of the term "components", considered as the "other constituents" with "no" impact on the plan?

"Ottoman Turks, not influenced by anything, had borne in themselves the vision and mentality that gave birth to Turkish 'landscape' gardens till they came to our country, and they created the compositions here by the very same inspiration" 8eldem, 1976, 341).

“(...)It is obviously futile and inappropriate to beso alienated from the Turkish culture to search similarities between Sa'dabad andMarly. What is more, Sadabad is completely loyal to the Turkish architectural style and decor, and it should be noted that the sadabad motif in French garden is done in a different way, always being related to the grotteand rocailleforms" (Eldem, 1977, 6).

Does trying to trace inherent "Turkish" characteristics by looking at the garden landscape and cascades, as is done in houses, point to that Turkishness actually exists everywhere that the eyes meet or that a Turkishness image exists in the writer's mind? Above all, can spaces be the embodiment of a "completely Turkish" or "pure" thought? And finally how can we talk about an unchanging "society" despite the many centuries that have passed?

"Another characteristic that distinguishes Turkish houses from those in modern European cities can be seen in the form of the houses.Houses are always flat, wide fringed, and roofed. Always the same type of tiles are laid on the roofs with the same angle. Thus, subsequent elements that are of equal value make up the fabric of houses. These horizontal lines are an expression of a settlement community that is aligned in rows behind or above each other, smoothly following the ascending, descending, and sloping nature. The facades of the houses can occasionally be seen between the roofs. Significant solidarity is noticeable on these facades also. The windows, the eyes of these facades, are of identical size and form. The number of them varies according to the sizes of the houses or roomsand, by increasing the number of the same elements, large facades of mansions and palaces are formed. It is the long facades of the mansions that make them discernable among the medium sized houses. These houses and mansions are so to speak the mirror of a group, the members of which are aligned in rows, knowing where the smallest and the largest members are andalwaysstaying in rowsnot daring to disrupt the order. Between the houses stand out large tree clusters andcypress trees looming uphere and there. They revive and revitalize the solemn urban fabric. On this dark colored and dull

5 Following the 'Introduction' between pages 19-80, the "The Classical Turkish House" section of this book restarts with page number 1 . background, sometimes white and silver mosque domes catch one's eyes" (Eldem, 1979a, XVII-XVIII).

Are the houses that build the "Turkish cities" comprised of the sameelements "always"?Are roof materials and shapes enough and necessary to envisage cities that belong to a nation? Are all the houses in these towns on the same slope and tile roofed?Aren't there any houses with earthen roofs or narrow eaves, or sheet coated steep slope houses? How is this possible that the windows are of the same length and shape? Are there not any flat or arched windows of varying sizes? Is it these similarities and the common sizing that establish the "solidarity", which is said to exist on the facades of houses? Why shouldsimilarity be called solidarity? Can the difference between an ordinary house and a palace be reduced to the sizeof structures andconsequently the number of windows? Perception of houses as "a mirror of society that knows its class/ethnic/religious place not daring to leave the row and disrupt the order"... what does it really indicate about the society and what does it really say about the social imagination of the writer? Is there a space which can act as the mirror of a society and depict it by architectural tools? Why does the thought of such a space conjure up houses and private spaces only? If houses and human beings are mirrorsof each other, and if a "solemn" society exists just like the houses that make up the "solemn"urban fabric and the "solemn" and "the tedious background", how can we think of a diversity of opinions in the society? What does a researcher who favors this imaginary monotony have to do with socialty?

"The Bosporus we know from the narratives of the Europeanhistorians and travelers is basically the creation of Turkish architecture, whichstarted to gain an identity in the 18thcentury. Beforethe invasion of Turks, this region was nothing more than a natural plot remote to the city, where there were fishing villages scattered here and there and abandoned monasteries" (Eldem, 1979b, VIII).

What is the meaning of a space "finding its identity"? Were the spaces of the earlier times, having different shapes, identityless?

"(...)It is noticeable that the houses built hundreds of kilometers away from each other and under different circumstances have architectural plans that are essentially always the same. The real structure of a house is expressed by its plan; again, the economic and social state of it finds a true reflection on the plan" (Eldem, 1984, 16) ${ }^{5}$.

"People of various countries, different climatic and topographic conditions, as wellas many other external factors led to the development of the Ottoman House, yet what brought all these together and blended them is the Turkish features that form the Ottoman-Turkish house, the Turkish art and Turkish culture. "Many 'non-Muslim and reaya ${ }^{6}$ ' factors contributed to the Ottoman House, which became more dominant throughout time, and some regional characteristics became prominent after the 18 th and 19th centuries, when these factors played a 
growing role in the development of craft and artisan trades. However, ultimately, elements which are quite alienated, even opposite, to each other have acted together towards the same direction and been shaped by the same mold, which was unique toTurkey, among many nations, thanks to the existence of the Turkish culture.

"The Ottoman house possessescommon characteristic features and motifs regardless of where it is located on earth, let it be in Crimea, Macedonia, Bosnia, Peloponnese, Anatolia, etc., which can only be explained by the Turkish heritage and the endless tolerance, encouragement, and protection it encompasses.The Turkish civilization, the Turkish house and life culture was so much above the existing ones wherever it was situated that it was instantly adopted and rooted. However, theturmoil of the 19th century couldundermine this impact, causing opposite reactions. Up until this, this unity had been able to live, nurture, and sustain as one single block. In the meantime, the local characteristics were not devastated and eradicated. On the contrary, especially due to religious power and exploitation of government sources in various ways, they from time to time flourished and got quite enriched. This entity once existed and flourished betweenEastern Europe and western Asia as a high level house civilization. On the edge of a powerful and culturally healthy nation, it exceeded boundaries and expanded the old areas" (Eldem, 1984, 19).

Is it possible to bring together all the factors that make up houses and "blend them in a pot" to get one single constituent? What is the significance of trying to identify a common feature that establishes the houses on an immense geography? How come can all these factors which are conceived as remarkably different from, even conflicting with, each other get into the "same mold"? Turkish nation is considered superior to other nations owing to its houses; and why is this so? How can the houses be accepted to be "rooted" in this claim to superiority? Are there also housing architectures that have not been rooted? Can houses built in different geographies and times gather under the same national definition? Did only people of Turkish ethnicity inhabit these houses, ordid they only build these houses, determining their architecture properties? How can the assumption of a holistic society living "as a block" indicate a comprehension of the world, politicallife, and culture? Why disregard the usual plurality of these houses and society, which are rendered anonymous each being likened to a "wild flower" and whose differences are ignored being likened to thehomogeneity of biologicalentities? Why is a conception of a "high-level house civilization" grown? What is implied here is the existence of "low level housing cultures in other geographiesand cultures", isn't it?

"First, as discussed earlier, protective changes took place with sofa(anteroom) andtaşlık (entry area covered with stones) and the use of glass was increased until there was no longer riwaq (roofless porch) ordireklik. What followed was the transformation in the characteristics of rooms. The divan started to disappear,replaced by bedsteads. Theusage of rooms changed, with some rooms being used as the bedroom, living room, and dining roomand parallel to these, the role of yüklük (cupboard) getting diminished. These changes are thosethat have been undergone by the mid-19th century. Construction techniques and policy also had an impact on the shapes of the houses.

"In brief, the development emphasized earlier in the text, is unrelated to the architectural style and architectural concerns" (Eldem, 1984, 40).

"In the late 18th and early 19th centuries, the architectural decor shifted from baroque to empire style. Nevertheless, the house designs continue to preserve the characteristics of the 18th century. Numerous houses belonging to this period were found in Istanbul and its environs, and they were amalyzed" (Eldem, 1987, 242).

If, by time, houses are being constructed by new techniques and decorated with new fashion of furniture, and if the usage style of these houses has transformed, how come can the lifestyles in these houses remain intact? Is itnotpossibleto endlessly hybridize different artifacts, different aesthetic preferences, and different housing cultures? Why do researchers hardly ever talk about it? Whichscale,apart from the schematic one,couldproduce the conclusion that house designs do not change throughout the changing time? Is it possibleto categorize the changes into two, those related with "architectural concerns" and those with the "style"? Why have somechangesbeen important throughout the time, while others have not?

The questions posed by Eldem's discussion on the vernacular architecture are applicable to the writing of other researchersfocusingon this subject. What follows is an elaboration of this.

\section{Erdem Aksoy}

"However, conditions in Anatolia are entirely different. Here, various climatic conditions collide and wildly different meteorologicaleffects are experienced in one season. This special geographical situation between Europa and Asiahasacted as a bridge, fostering the migratory and tribal movements between these continents since ancient times. Thus, various cultures established on Anatolian land created diverse realms of form as a result of different climatic effects, which can be divided into regions across the country" (Aksoy, 1963, 44).

To what extent does the deterministic approach, which regards climatic features as the deciding factor in the emergence of a house, make sense? Why is the Anatolian climate considered "totally different" from other climates and seen influential in the development of houses? Were the houses constructed in this large geography, which has fluctuating climatic conditions, designed in a way that they would be suitable for all climatic conditions? Don't these varying climaticconditions apply to Germany, France, England, etc.? How can climate make Turkey unique?

"More importantly, it must be admitted that Turks have a space notion. At this point, the explanation providedin the introductionneedstobe recalled to see the main cause of the problem: Oghuz 
tribes had been migrating for centuries, and this migratory movement was to bring a life style different from the one encountered in regular nomadicmovementsbetween summer and winter places. Actually, Oghuz tribes had been searching for a certain homeland, or a region where they could settle. The conditions of Asian steppe, which were unsafe and unsuitable for settlement, obliged them to continuously change their homeland, thereby dissolving from the land the consciousness of place and feeling of motherland and developing a new, abstract spaceconsciousness.A restrictive inner space against the eternity of the protective steppe and an environment created personally were profoundly sought for. This need must have been fulfilled in the open central spaces of the southeastern Anatolian courtyard houses, the open rooms or hayat of the Mediterranean coast, and finally in the interior glass anterooms of the Istanbul houses, the peak of development" (Aksoy, 1963, 69).

How can a 'spaceconsciousness develop some time in the past in a particular space and maintain for thousands of years? What is the point in attributing all the houses throughoutAnatolia to one single origin? As regards the vernacular house, why is the concept of an outcome starting from a point and getting stabilized preferred to that of a formation process without a beginning and end? Can the houses be homogenized as the concretization of space consciousness, which is thought to have originated from the Asian steppe and to have emerged as a result of nomadism? Does a national/ethnic/religious/etc. awareness of space exist anywhere on earth, apart from Turkey? Can sofas, which are a part of houses, be considered more important than other spaces and a representation of a many centuries old lifestyle? Why was the anteroom so vital, but not the kitchen, toilet, rooms, roof, construction, and adornments?

\section{Önder Küçükerman}

"The 'room' of the Turkish house gained important characteristics in the Settlement period. These are direct reflections of social structure on buildings. The usage conditions of a room are the factors that shape it. When the space use of the Turkish house and room in this period is compared with that in the nomadic tent, remarkable commonality in terms of essence is recognized: As can be seen in the examples comparing the tent and the room intermsof this criterion, because the acts are alike, the sizes are close to each other. The materials and techniques used in framing and coating the internal structure reveals the general form. The roundedness in the tent caused by the material turned intoright angled shapes. The area allocated to balesand chests in the tent became the closet and its extensions in the room, or the 'closed usage area'. "The internal layout has still been being modified to cater for the actsof the tent, such as eating, working, and sleeping" (Küçükerman, 1973, 52).

Why is the "room", a section of the house, regarded more decisive than other sections? What is the significance of drawing an "essence" connection between the tentandroom? Can we conceive of an unchanging "essence" annihilating the meaning of changes in the lifestyle habits? Is the similarity between the actions taken in settlement spaces enough itself for the conception of essence? What is the motive behind the pursuit of an unchanging concept of essence throughout history?

"An analysis of the houses built on two divergent types of nature, a steep slope and flat ground, reveals a conclusion that almost never changes. None of them display any contradiction with general principles as regards the internal layout of the building and rooms, building principles, andthe basic concepts about the interaction withthe environment. That is, the most important section of the house, the main room (baş oda), was opened in a way that best fits the environment. Onthe other hand, other rooms are closed outwards" (Küçükerman, 1995, 65).

What is the meaning of regarding the room space as constant at a certain time and determining a hierarchy of the factors that transform and do not transform it? How can one order the spaces that constitute a house by degree of importance? Why are spaces described as being not against when they are alike? Wouldit be unthinkable to see elements that are against in a houseorany other structure? Do architectural products show an absolute internal consistency that does not deviate from the general principles preached from the beginning? Do architectural products show an absolute internal consistency that does not deviate from the general principles laid down in the first place.

\section{Ayda Arel}

"We principally tend to believe some features of spatial organization of the Ottoman housederive from the cultural background that had created this type ofhouse.We preferred methodologies from semiotics to demonstrate the clash between spatial order and cultural ideology.

"An analysis of the Ottoman house reveals that this house is made up of certain conflicts and the basic typological order finds expression in these conflicts: The contrasts between rooms and common spaces, spaces indoor and outdoor, the ground floor and the living floor, the main room and other volumes, harem and the men's room, seatingareaand the circulation area, and winter and summer sections are all relations that gain meaning along a sequence of values from the functional to the symbolic" (Arel, 1982, 78).

"Our examination demonstrated that main values, habits, and tendencies that belong to the syncretic Ottoman culture were reflected on residential designs with 'varying degrees, and in some cases, in different forms' depending on the chronological and environmental factors. These values sometimes maintain their existence as a symbolic image, or icon, which have drifted away from their real cultural meanings. For example, throughout the process from the imperial tent to the main room, the risingmotifabandoned its real meaning, but has survived equipped with new meanings and retaining 
someof its indispensable formal characteristics" 7 (Arel, 1982, 80).

Why are "the principles" that make up the house searched in a typological way? Aren't the principles described and searched through "conflict" a consequence of a pursuit of orderliness, just likeprinciples of concordance? Is it possible to list the items that are to be included in the concept of cultureand to select, from among these, the "major"ones and those that willbe considered secondary? Is it possible to discover the principles that make up a house by reducing such a large scoped concept as "culture" entailing all that exists in nature as well as the human beings? Is it possible to formulate this? Why is there such a need for this formula?

\section{Cengiz Bektaş}

"There are architects of these structures, though not in the sense today. Architects, or ratherconstructors, masters, humble and anonymousartistssucceeded in making their works anonymous... Most of the certified architects today have been detached from these masters. However, it is by learning from their works of art that avoiding alienation, sophistry, and fake and pretentious styles will be somewhat easier" (Bektaş, 1980, 9).

"The ESSENCE can only be attained through respect for the REAL and cognizance of one's own ESSENCE, or REAL.Imitating is not respect. Only a truly contemporary building would suit next to a building that is the real product of its age" 8 (Bektaş, 1980, 17).

What does a desire for anonymous houses mean? Why is architects' learning something from other structures, approaches, and societies in the world during their architectural design regarded negatively? Is it bad to be a wannabe or pretentious, or to imitate a design? Can't this simply be a practice of learning? Why is it called "sophistry"? What is "essence" and "the real", and why is it important?

"The most important feature of the building art of Anatolia, especially of our people, is the integrity of the essence and form" (Bektaş, 2012, 45).

"The essence has prominence even in this integrity. It gives birth to form... A similar situation was experienced in the Republican period in the mid1930's. However, it did not last long; fascist Europe influenced our society immediately. The link between the essence and form leads to certain conclusions pertaining to the culturallevel of the society:

- In a society where trendy forms without any essence prevail, culture production lags far behind the contemporary. In other words, in such a society, culture

\footnotetext{
7 In her work, formulates the characteristics that create the "Ottoman House" by means of a painting called "The development of the Contradiction Principles governing the Foundation Order of the Building in a Traditional Ottoman House".
}

8 As previously explained, some words or concepts in the quotations referred to in this article are written in bold fonts to is not produced; whatever is committed in the name of culture are all superficial and deceptive.

- The forms that are transferred from other societies and "essence"less according to societal criteria and problems is evidence to the fact that our society has turned into a copycat society. It means the futureof our culture is at a dead-end. In a society, culture and money hardly ever side with each other" (Bektaş, 2012, 46) .

What is the conception of atotalityrelation between form and"essence"? Why is essence, according to this conception, considered superior because it determines the form? Can we make such a generalization as the level of culture in a society? Is culture a "given" concept described by an "essence" other than human beings? What does the imagination of "forms with an essence" imply?

\section{Doğan Kuban}

"Hayat 9 , invites one directly to home. Like halaniortarma,hayat is one of the main features adding to the interesting Turkish house experience or even creating it. The spatial organization of this open gallery is the living dimension of the house. In the history of architecture, semi-open gallery, riwaqporch, alcove (cumba), and the most integrated example of these, the courtyard with riwaq have been the most attractive elements of architectural style. Hayat can also be interpreted as a developed form of riwaq integrated with all the activities and elements of the house. It has never been a neutral gallery, a balcony, or a simple roaming area. Hayat constitutes half of the house and its whole facade with the rich details on its edges, versatility on space use, its expansion and enhancement by iwans, and its coverage of the house not only longitudinally but also diagonally. It is the fundamental element in the design of the house. The details of hayat is what gives identity to the rooms. The stairs visible from the courtyardvividly displays the function of hayat" (Kuban, 1995, 215).

"The design principal of The Turkish HayatHouse, which has never changed since the beginning of its evolution, stands in contrast to the hayat-room (life room) that I have brought up many times earlier. While the elements are used with considerable freedom, their hierarchical order does not change.Life and form are intertwined in the design of room and hayat' (Kuban, 1995, 223).

Can a space of a house be described with the following phrases: "inviting the residents directly to home", "the most attractive section", "and the living dimension of the house"? Are there sections of the house that are nonliving? Why, among many sections of the house, is one pointed as the "main element"? What does the claim that spacesgive "identity" to the rooms aim? Is it possible to imagine a house as a constantly same

draw attention. However, the use of upper-class letters with some words in these quotations is the choice of the writer. The convergence in the expressions was performed through conflicting ideas. The writer intends to highlight the "essence" concept in this quotation, believing there is an "essence" and stressing it.

${ }^{9}$ Hayat: Exterior sofa 
spaceand accept that this space has a "design principle that has been unalteredfromthe beginning"?

$$
* * *
$$

Vernacular architectural discourses are not multivocal; indeed, they are a cluster of discussions revolving around the same concepts and conclusions.Actually, this indicates more about the society producing those discourses, rather than about architecture. These arguments frequently stress that a society and culture have a fixed essence and there are spaces compatible with it. Put differently, social and physical determinism coexist in these arguments, wherein there is also evidence of approaches that are somewhatculturalist, climatic, and historical determinism. It can be inferred that, with these determinist discourses, a political power is conceived of and the major constituent of this conception is "essentialism". Essentialism is embodied in the culturalist deterministic discourses through the definition of the "essence" of "Turkish culture" by vernacular architecture; it is embodied in the climatic deterministic discourses through the claim that the "essence" constituting the "Turkish settlement structure" has emerged following the climate andtopographycharacteristics; in the historical determinism, on the other hand, it emerges in the form of connections established between "tent", "room", and "Turkish house", which share the same "essence". Further studies should be conducted, focusing on whether "essentialism" oriented vernacular discourses, or any form of their extension or implication, are still produced or not.

Asstated previously, the second part of the article intends to perform a psychoanalytical analysis of the vernacular to comprehend the essentialism oriented discourse of the Turkish vernacular. This is an analysis conducted through the "unspoken", rather than the spoken, about the vernacular discourse. As is wellknown, similar to the discrepancy between the spoken and the unspoken in all social relations, the sociality has two opposite sides like an iceberg 10: The visible spoken and, the more robust, the invisible unspoken. Therefore, the second part of the paper deals with the unspoken side of vernacular, which is somewhat a component of sociality.

\footnotetext{
10 This metaphor belongs to Bülent Diken.

11 "To know and not to know, to be consciousofcomplete truthfulness while telling carefully constructed lies, to hold simultaneously two opinions which cancelled out, knowing them to be contradictory and believing inbothofthem; to use logic against logic, to repudiate morality while laying claim to it, to believe that democracy was impossible and that the Party was the guardian of democracy; to forget whatever it was necessary to forget, then to draw it back into memory again at the moment when it was needed, and then promptly to forget it again; and above all, to apply the same process to the process itself. that was the ultimate subtlety: consciously to induce unconsciousness, and then, once again, to become unconscious
}

\section{Speaking the Unspoken About Vernacular}

A myriad of practices constitute sociality. Indeed, Simmel advocates dealing with interactions that can be reached through psychological microscopy, rather than what the social sciences generally do, i.e., handling only the very big and clearly seen social structures and by looking at them, developing insight into the larger social life. Here lies the interactions among the societies of atoms, which can only be reached by means of psychological microscopy and which support the social life's entire strength, flexibility, diversity, and uniformity, which is as much clear as it is confusing (Simmel, 2009, 219-220).

Sociality is established by vernacular, as well as with countless practices. This establishment is actualized by vernacular not only as an architectural product but also as a discourse. This section does not deal with the discourse of the vernacular architecture, nor does it with what is stated in the vernacular discourse: it deals with the "unspoken". In other words, to fully comprehend the vernacular, it attempts at a subconscious reading of it, rather than a straight reading, and while doing so, it especially draws on Žižek's Sublime Object of Ideology.

The unspoken may conjure up the "doublethink"11 process in Orwell's dystopic novel 1984 (Orwell, 2015, 59). As is well-known, in this novel, the ever-narrowing language of the state Ocenia, "Newspeak", works with the doublethink process. "It means holding two contradictory beliefs in one's mind simultaneously and acceptingboth" (Orwell, 2015, 245). For example, in the novel, the name of the ministry in charge of distorting the reality is "Ministry of Truth", which occurs through doublethink.By means of this, the reality is always subjected to inspection, so a society deprived of its memory and past is produced. If not exactly in the sense depicted in the novel, it is also possible today to encounter the unspoken, or cautious and implicit discourse, hinting that the truth is under surveillance.

To see the unspoken in a discourse, Foucault searches its connections by using a method he calls archeology $^{12}$ (Foucault, 1999, 64). For him, Panopticon is a machine designed to discipline and normalize the modern society, whereas Bentham claims it was designed for correctional training of the criminal and their transition back to society. Žižek also maintains that the unspoken is more common than the spoken in the discourses, and thus the discourses should be approached with the "awry look". If we look directly at something, we will see it as it really is; however, a look

of the act of hypnosis you had just performed. 'Even to understand the word 'doublethink' involved the use of doublethink".

12 "Discursive relations are not, as we can see, internal to discourse: they do not connect concepts or words with one another; they do not establish a deductive or rhetorical structure between propositions or sentences. Yet they are not relations exterior to discourse, relations that might limit it, or impose certain forms upon it, or force it, in certain circumstances, to state certain things. They are, in a sense, at the limit of discourse". 
intermingled with our desires and anxieties ('awry look') will give us a distorted and obscure image. On the other hand, a direct opposite relation exists on the level of the second metaphor: If we look at something straight, i.e., through an impersonal and objective perspective, we cannot see anything other than an amorphous point; the entity gains a clear meaning only when we look at that from a certain angle, i.e., through a personal look accompanied, penetrated and distorted by the desire" (Žižek, 2010, 27).

The unspoken can be regarded as an ideological fantasy. A glance at the ideology and its fantasy dimension will better explain this. Žižek asserts that ideology can define everything, from mere contemplative attitude that misunderstands its adherence to social reality to a set of action-oriented believes, from the inevitable realm wherein individuals experience their own relations to wrong conceptions legitimizing the dominant political power, and to the socialstructure (Žižek, 2013, 11). As can be seen in this definition, the ideology concept has become stronger in time to such an extent that it has started to embody everything. According to Žižek, this is why the concept has been increasingly abandoned. Especially when we try to avoid ideology, it suddenly emerges in front of us, and when one wishes to focus on it, it fades away. As regards the fantasy dimension of ideology, the concept should be associated with psychoanalysis. Lacan, who has carried out several studies on this topic, uses "desire" as the most important concept to comprehend psychoanalysis. According to Lacan, desire is not only an individual but also a social mechanism, and the social characteristic of desire is that one desires when he or she is desired. That is, the desire is the other person's desire, and as it is unique to socialty but not to individuality, it is related to psychoanalysis but not to psychology. Just like the subject, the community itself, which consists of individual subjects, desires because it is amiss and filled with longing for completeness. Lacan asserts that the person who wants to be a subject and the collective who wants to be a society resort to the "fantasy" technique to handle this problem. Hebasically views fantasy as a scenario filling the hollow space of an impossibility and a cover masking the void" (Žižek, 2015, 143), and reminds that, with a commonly used technique, personal and social disintegration are shown to be nonexistent. Lacan sheds light on this issue by giving the example of the purest form of ideology, antisemitism. As can be seen in antisemitism, the Jewish fantasy was created as the force to disrupt the integral society-the German society, thereby obscuring the impossibility of such a society. Put differently, owing to the Jewish fantasy, the illusion of a non-disintegrated society was created 13 (Žižek, 2015, 142). The function of ideology here is to cause the perception that something that had never actually existed was stolen or lost, and thus the perception that it had existed.

What can be seen if the vernacular discourse, an element of socialism, is considered with Lacan's psychoanalytic method? First of all, to reach the subtext of discourses in this method, one should scrutinize whatever is longed for or whined about when it is absent. In the vernacular discourses in Turkey, generally a certain type of organic society-Turkish society- is envisaged, and the values that this society once possessed but later lost are often yearned for. Similarly, cities are assumed to have had identities in the past, which were later lost. "Turkish culture" is affirmed; "Ottoman House" and "Turkish House" are said to reflect this culture; "extinction of this culture" causes discomfort, and recreation of this bygone culture is wished for. This rhetoric advises that we turn to the "essence" to "find" the identity or culture a city or a society has lost, and thus that we look at the vernacular.

On this, Diken and Laustsen maintain that the fantasy logic of the rhetoric that focuses on the "original city" (which can also be called as the "authentic city" or the "essence"), whose identity is said to have been lost, is nostalgic and that the wholeness of the city is often referred to as something lost, devastated, or stolen: "The modern city is deprived of something wiped out by modernism, and that supreme thing is believed to be what would have gained the city its identity if it had not been lost" (Diken and Laustsen, 2010, 110).

The vernacular rhetoric about an "identity" that is stated to have once existed in the cities and the "essence" that forms this identity conjure up a related and striking critique of Žižek. He claims that whenever one pretends to profoundly discuss some topics about which little is known, he or she always talks about the "essence": "Let us assume that, in a political meeting or academic conference, we are expected to express our deep thoughts about the sad and miserable situation of homeless people in big cities, and imagine that we have no idea whatsoever about their real problems. The only way of saving face is to create the effect of depth with a pure formal reversal: Today we must all have heard and read about the difficult lives, sad and miserable conditions of the homeless in our cities. Perhaps, however, the gravity of the situation is a sign of greater gravity. It is the reality that the modern man can no longer have a proper place of dwelling. The human beings have increasingly become alienated from their own life. Even if we build new places to accommodate all the homeless, the main source of problem is maybe something greater. The essence of homelessness is the very homelessness of the essence; in our world corrupted by frantic quests for vain pleasures, it is the reality that there is no home or dwelling suitable for the human being's actual essential aspect" (Žižek, 2013, 31).

According to Žižek, who adapts these formal matrices to different cases, the pure formal operation that creates the depth effect is perhaps the purest form of ideology in all these cases.

It is quite common practice to create the effect of depth by means of rhetoric that revolves around the "essence" in the vernacular discourse. Here, the vernacular is no less functional than antisemitizm, which Lacan cites as an example to the purest form of ideology. Just as the "Jews" describe the integrative German society with a desire to differentiate yet at the same time to unify, so do the vernacular discourses in Turkey describe the lost values, while producing the illusion of regaining the homogenous Turkish society. The pursuit

13 "Society doesn't exist, and the Jew is its symptom". 
for a totalitarian society in these discourses is due to a desire for leading identical lives in houses of the same quality and aesthetic features. Such a community is conceived of as one without uncertainty, chaos, and hardship. At this point, the role of ideological fantasy is to make us believe that values such as identity and culture, mostly referred to as "essence" in this text and depicted as something lost, did exist in the past. Nevertheless, when the vernacular is needed during the quest for the "essence", it acts to conceal the fact that the "essence" does not have any reality.In brief, when the unconscious is interpreted this way with the vernacular discourses, an integrative society could be envisaged. Through this envisagement, an architecture based on the same "essence" can be discussed, and structures regarded as the products of a history written in a certain way can be treated superior to others. From this point of view, vernacular discourses seem to be hiding the wellknown fact that there is no such thing in any society as an "essence" that has reached today intact and "identical" residences and people.

\section{References:}

Aksoy, E. (1963). "Ortamekan: Türk Sivil Mimarisinde Temel Kuruluş Prensibi"/ Central space: Basic Structural Principle in Turkish Civil Architecture, Architecture and Art, Volume: 7-8, p. 39-91.

Arel, A. (1982). Osmanlı Konut Geleneğinde Tarihsel Sorunlar/The Problems of Ottoman Housing Tradition, İzmir: Ege University Faculty of Fine Arts, Design and Architecture Publishers.

Bektaş, C. (1980). Antalya, Antalya: Municipality of Antalya Publishing.

Bektaş, C.(2012). Sevgi Örülünce Yapıda/When Love and the Building Knit Together (Mimar Sinan), ed.: Nezih Başgelen, İstanbul: Archeology and Art Magazine; inc. "Essence/Form", p. 44-46.

Benjamin, W. (1993). Son Bakışta Aşk, editor: Nurdan Gürbilek, İstanbul: Metis Publishers.

Diken B., Laustsen, C. B. (2010). Filmlerle Sosyoloji/Sociology through the Projector, İstanbul: Metis Publishers.

Durkheim, É. (2016). Sosyolojik Yöntemin Kuralları/The Rules of Sociological Method, Translated by: Özcan Doğan, Ankara: Doğu Batı Publishing.

Eldem, S. H. (1968). Architectural Plan Types of Turkish House, İstanbul: ITU Journal of the Faculty of Architecture.

Eldem, S. H. (1976). Türk Bahçeleri/Turkish Gardens, İstanbul: Ministry of Culture and Tourism Publishing.

Eldem, S. H. (1977). Sa'dabad, İstanbul: Ministry of Culture and Tourism Publishing.

Eldem, S. H. (1979a). İstanbul An1lar1/İstanbul Reminiscences, İstanbul: Aletaş Alarko Education Facilities Inc. Publication.
Eldem, S. H. (1979b). Boğaziçi Anıları/Reminiscences of the Bosphorus, İstanbul: Aletaş Alarko Education Facilities Inc.Publication.

Eldem, S. H. (1984). Turkish Houses Ottoman Period I, Journal of The Foundation for the Conservation of Turkey's Monuments, Environment and Tourism Assets.

Eldem, S. H. (1987). Türk Evi Osmanlı Dönemi III/Turkish Houses Ottoman Period III, Journal of the Foundation for the Conservation of Turkey's Monuments, Environment and Tourism Assets.

Foucault, M. (1999). Bilginin Arkeolojisi/l'archaeologie du savoir, translated by Veli Urhan, İstanbul: Birey Publishing.

Kuban, D. (1995). Türk Hayat'lı Evi/The Turkish Hayat House, İstanbul: Ziraat Bank Cultural Publications.

Küçükerman, Ö. (1973). Anadolu'daki Geleneksel Türk Evinde Mekan Organizasyonu Açısından Odalar/ The Rooms in the Traditional Turkish House of Anatolia from the Aspect of Spatial Organization, İstanbul: Magazine of Turkey Touring and Automobile Club.

Küçükerman, Ö., Güner, Ş. (1995). Anadolu Mirasında Türk Evleri/Turkish Houses in Anatolian Heritage, İstanbul: Republic of Turkey Ministry of Culture andTourism Publishing.

Lefebvre, H. (2015). Mekanin Üretimi/Production de l'cspace, Translated by: Iş1k Ergüden, İstanbul: Sel Publishing.

Simmel, G. (2009). Bireysellik ve Kültür/On Individuality and Social Forms, translated byTuncayBirkan, İstanbul: Metis Publishers.

Orwell, G. (2015). 1984, translated by CelâlÜster, İstanbul: Can Publishing House.

Žižek, S. (2010). Yamuk Bakmak/Looking Awry An Introduction to Jacques Lacan through Popular Culture, translated by Tuncay Birkan, İstanbul: Metis Publishers.

Žižek, S. (der.) (2013). Mapping Ideology, translated by Sibel Kibar, Ankara: Dipnot Publishing House.

Žižek, S. (2015). İdeolojinin Yüce Nesnesi/ Sublime Object of Ideology, translated by Tuncay Birkan, İstanbul: Metis Publishers. 